\title{
Open surgical management of a ruptured intracranial aneurysm in Klippel-Trenaunay-Weber (KTW) syndrome
}

\author{
Adam Derik Smitherman, Michael Neil Woodall, Cargill H Alleyne Jr, \\ Scott Y Rahimi
}

Department of Neurosurgery, Georgia Health Sciences University, Augusta, Georgia, USA

\section{Correspondence to}

Michael Neil Woodall, mneilwoodall@gmail.com
To cite: Smitherman $A D$, Woodall MN, Alleyne C H Jr, et al. BMJ Case Reports Published online: [please include Day Month Year] doi:10.1136/bcr-2012006857

\section{SUMMARY}

A 24-year-old man with a history of Klippel-TrenaunayWeber syndrome presented with severe headache and neck pain. Work-up revealed subarachnoid hemorrhage and evidence of multiple intracranial aneurysms. The patient was treated with open surgical clipping of his ruptured aneurysm and is currently doing well.

\section{BACKGROUND}

Klippel-Trenaunay-Weber (KTW) syndrome is characterised by asymmetric limb hypertrophy, cutaneous haemiangiomas and varicosities. There have been few reports of KTW patients harbouring intracranial aneurysms. There have been only two prior cases reported of open surgical management of intracranial vascular lesions in KTW patients. ${ }^{12}$ This is the first known report of successful open clipping of a ruptured aneurysm in an adult patient with KTW.

\section{CASE PRESENTATION}

A 24-year-old man with a history of KTW syndrome presented with severe headache and neck pain after falling out of bed. He had a brief loss of consciousness at that time. He was then brought to the emergency room where he showed nuchal rigidity and no neurological deficit.

\section{INVESTIGATIONS}

Initially a CT scan revealed a subarachnoid haemorrhage. This later prompted a cerebral angiogram

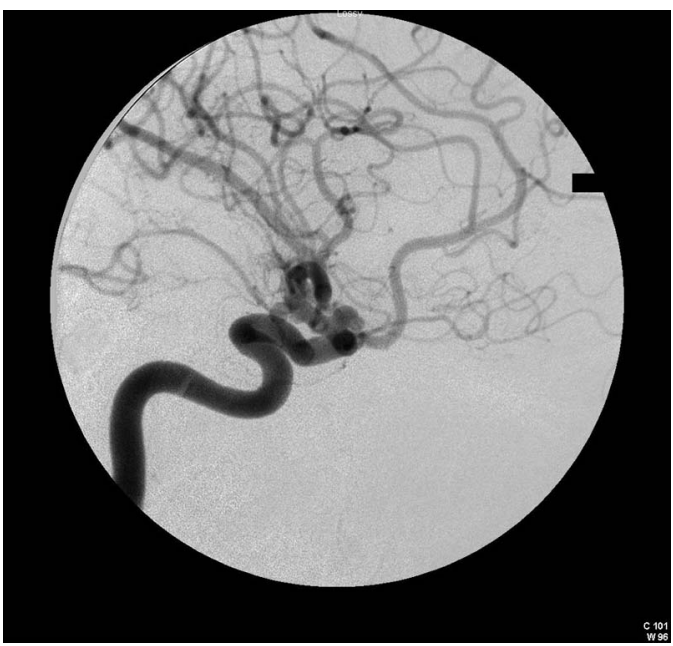

Figure 1 Cerebral angiogram, left lateral internal carotid artery injection. which revealed multiple intracranial aneurysms including a $4 \mathrm{~mm}$ left ophthalmic artery aneurysm, a $5 \mathrm{~mm}$ left anterior choroidal artery aneurysm, a blister aneurysm of the left supraclinoid internal carotid artery and a right posterior communicating artery blister aneurysm (figure 1).

\section{TREATMENT}

He was taken to the operating room for surgical clipping of the left anterior choroidal and ophthalmic artery aneurysms and wrapping of the blister aneurysms. Intraoperatively, a several millimetre segment of the supraclinoid internal carotid artery (ICA) appeared irregular and diseased.

\section{OUTCOME AND FOLLOW-UP}

His postoperative course was complicated by right hemiparesis due to a left anterior choroidal artery infarct likely due to vasospasm as well as an upper gastrointestinal bleed. He ultimately recovered, returning to his neurological baseline.

\section{DISCUSSION}

KTW syndrome is characterised by asymmetric limb hypertrophy, cutaneous haemiangiomas and varicosities. There have been few reports of KTW patients harbouring intracranial aneurysms. There have been only two prior cases reported of open surgical management of intracranial vascular lesions in KTW patients (figure 2). ${ }^{12}$



Figure 2 Extremity soft tissue and bone hypertrophy. 


\section{Learning points}

- Klippel-Trenaunay-Weber syndrome is a relatively rare condition characterised by asymmetric limb hypertrophy, cutaneous haemangiomas and varicosities.

- Rarely, this patient population can harbour intracranial aneurysms.

- Open surgical treatment is a viable option for acute rupture of intracranial aneurysms in this patient population.
Competing interests None.

Patient consent Obtained.

Provenance and peer review Not commissioned; externally peer reviewed.

\section{REFERENCES}

1 Al-Salman MM. Klippel-Trenaunay syndrome: clinical features, complications, and management. Surg Today 1997;27:735-40.

2 Star A, Fuller CE, Landas SK. Intracranial aneurysms in Klippel-Trenaunay/Weber syndromes: case report. Neurosurgery 2010;66:E1027-8; discussion E28.

Copyright 2013 BMJ Publishing Group. All rights reserved. For permission to reuse any of this content visit http://group.bmj.com/group/rights-licensing/permissions.

BMJ Case Report Fellows may re-use this article for personal use and teaching without any further permission.

Become a Fellow of BMJ Case Reports today and you can:

- Submit as many cases as you like

- Enjoy fast sympathetic peer review and rapid publication of accepted articles

- Access all the published articles

- Re-use any of the published material for personal use and teaching without further permission

For information on Institutional Fellowships contact consortiasales@bmjgroup.com

Visit casereports.bmj.com for more articles like this and to become a Fellow 